by Partha Pratim Chakraborty ${ }^{1}$, Joydip Mukhopadhyay², Pritam P. Paul ${ }^{3}$, Dhiraj Mohan Banerjee ${ }^{1}$ and Melinda K. Bera ${ }^{4}$

\title{
Early atmosphere and hydrosphere oxygenation: Clues from Precambrian paleosols and chemical sedimentary records of India
}

\author{
1. Department of Geology, University of Delhi, Delhi-11007 \\ 2. Department of Geology, Presidency University, Kolkata- 700073 \\ 3. Department of Earth Sciences, Indian Institute of Technology, Mumbai- 400076 \\ 4. Manav Rachna University, Faridabad, Haryana, India - 121004 \\ Corresponding author E-mail: parthageology@gmail.com
}

(Received : 23/02/2019; Revised accepted : 13/11/2019)

https://doi.org/10.18814/epiiugs/2020/020011

A number of Precambrian sedimentary basins of the Indian subcontinent offer scope for tracking early oxygenation history of atmosphere and hydrosphere. Available studies, though certainly not exhaustive, record signatures of pre-great oxygenation event (GOE) whiffs of atmospheric oxygenation between 3.29 and $3.02 \mathrm{Ga}$. Besides, available geochemical signatures from Precambrian sedimentary rocks (BIF, sulfides, sulfates, argillaceous sediments and phosphorites) suggest a generally sub-oxic shallow marine and bipartite oxicsulfidic condition in late Paleoproterozoic and Mesoproterozoic time, respectively. In this backdrop, occurrence of phosphorites in several late Paleoproterozoic basins possibly indicates formation of local oxygen oasis in presence of cyanobacterial community. From heavy to very heavy $\delta^{34} S$ values in sulfides (pyrite) present in a number of Mesoproterozoic basins and Mo, Mo/TOC values from argillaceous intervals of the Vindhyan Supergroup, it is inferred that the deep hydrosphere was, in general, anoxic and, at times, euxinic.

\section{Introduction}

The Proterozoic Eon (2500-541 Ma before present, Gradstein et al., 2012) encompasses more than $40 \%$ of the Earth history and represents an unique time period that witnessed amalgamation and breakup of supercontinents (Dalziel, 1997) with growing importance of Phanerozoic-style plate tectonics (Nelson, 1998; Nelson et al., 1999), dramatic oceanic and atmospheric changes on global scale
(Hoffman et al., 1998), biological evolution leading to the advent of multicellular life (Knoll, 1994) and major changes in the upper crustal composition (Taylor and McLennan, 1997). None of these changes followed uniform and steady character e.g., Paleoproterozoic (2500 $1800 \mathrm{Ma}$ ) and late Neoproterozoic (800 -541 Ma) witnessed major biological, tectonic, climatic and atmospheric changes. The billion year interval (1800 - $800 \mathrm{Ma})$ mostly encompassing the Mesoproterozoic time on the other hand is marked by tectonic, climatic and evolutionary stability (Reddy and Evans, 2009; Mukherjee et al., 2018). Nevertheless, amongst above mentioned breakthrough changes, the most debated one is oxygenation of Proterozoic atmosphere and hydrosphere, since it is intimately tied up with appearance and proliferation of life. It is generally believed that despite the early appearance of cyanobacteria and initiation of oxygenic photosynthesis well before the Great Oxydation Event (GOE) (Farquhar et al., 2011), the early atmosphere remained reducing in nature with reduced gases e.g., $\mathrm{CO}, \mathrm{NH}_{3}, \mathrm{H}_{2} \mathrm{O}, \mathrm{H}_{2}, \mathrm{CH}_{4}, \mathrm{CO}_{2}$ and $\mathrm{N}_{2}$ as main constituents (Shaw, 2014; Kanzaki and Murakami, 2015). A combination of processes viz. a switch from dominant submarine to subaerial volcanism, gradual oxidation of continents and concomitant decrease in reduced metamorphic gases, a decline in nickel availability and deposition of banded iron formation caused change in the fluxes of oxidants and reductants to the Earth's surface to promote photosynthesis (Kasting, 2013) and led to the rise of $\mathrm{O}_{2}$ at the GOE (2.4 to $2.3 \mathrm{Ga}$ ago). The idea that concentration of $\mathrm{O}_{2}$ in the atmosphere rose modestly for the first time (i.e $<0.001 \%$ to $>0.1 \%$ of Present Atmospheric Level, PAL) at the GOE and further waited patiently for about two billion years to rise to a higher level in Neoproterozoic Oxygenation event (NOE; Och and Shields-Zhou,2012) is contested in recent studies by Lyons et al., (2014); Crowe et al., (2013) and Mukhopadhyay et al., 2014), wherein evidences for whiffs of rise in atmospheric oxygen are put forward well before the GOE. In fact, dynamic scenarios that have emerged in recent studies include possibility of a much larger $\mathrm{pO}_{2}$ early on at the GOE, which is followed by a deep plunge to a lower level $(<<0.1 \%$ PAL) in next billion year 

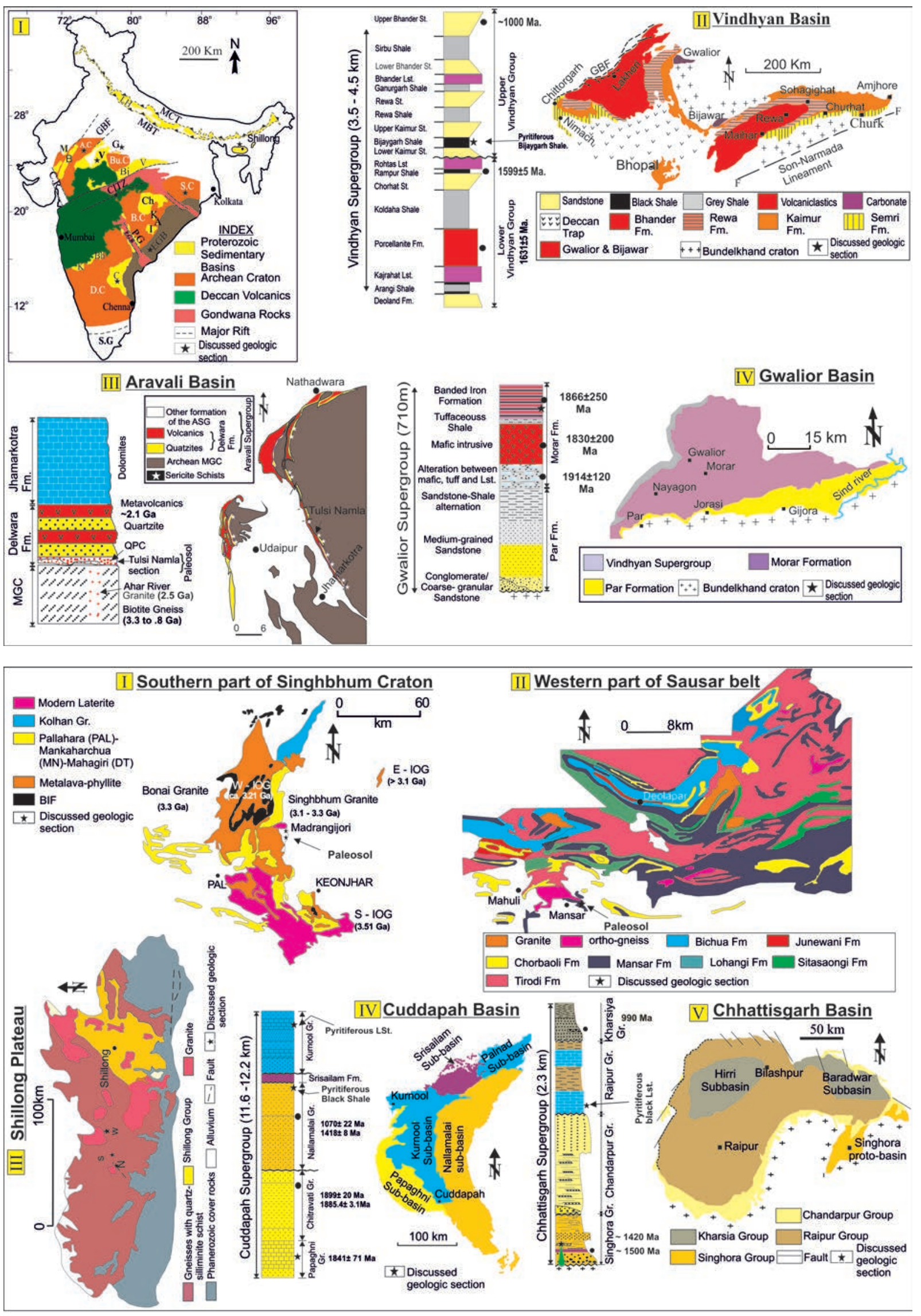

Figure 1. Generalized geological map of peninsular India (star marks indicate discussed sections; a) detail geological map and lithostratigraphy (with available geochronology data) for the Vindhyan basin, Aravalli basin and Gwalior basin; b) detail geological map and lithostratigraphy (with available geochronology data) for the Singhbhum craton, Sausar craton, Shillong plateau, Cuddapah basin and Chhattisgarh basin. 
until it raised again at the NOE (1000-541 my before present) under the combined influence of. i) intense chemical weathering of early Neoproterozoic continental landmass assembled near paleo-equator, ii) weathering of Large Igneous Provinces (LIPs) and enhanced supply of phosphorus (P) in ocean iii) organic bloom in ocean triggered by enhance availability of phosphorus vis-à-vis increased carbon burial (Planavsky et al., 2015).

More dynamic and debated oxygenation history has been proposed for the Proterozoic hydrosphere. While a strong school (Canfield, 1998; Scott et al., 2008; Planavsky et al., 2011; Reinhard et al., 2013 and many others) believes in stratified ocean model with near oxic surface water and euxinic and/or ferruginous deep water in late Paleoproterozoic and Mesoproterozoic, the other view (Planavsky et al., 2014; Tang et al., 2016) advocates relatively low oxygen concentration $(<0.2 \mu \mathrm{m} /$ litre $)$ in shallow seawater till mid-Proterozoic ( $1.54 \mathrm{Ga})$. Opinions vary widely for oxygenation of deep-ocean as well. From disappearance of iron formation (BIF) in rock record, Holland, (1984), Holland \& Beukes (1990) contemplated beginning of deep ocean oxygenation at c. $1.8 \mathrm{Ga}$, which did not get support from studies on biomarkers of sulphur bacteria (Brocks et al. 2005) and $\mathrm{Mo}, \mathrm{Sr}, \mathrm{Cr}$ and S isotope compositions in black shales (Arnold et al. 2004) and pyrites (Canfield, 1998, 2004; Poulton et al., 2004). Low trace element and phosphorous $(\mathrm{P})$ concentrations in marine black shales allowed workers to believe continuation of the sulphidicanoxic deep ocean throughout the Mesoproterozoic and parts of the Neoproterozoic until the $\mathrm{pO}_{2}$ approached modern levels after $c .1$ Ga. A third view (Slack et al., 2007) claims sub-oxic condition with low concentrations of dissolved $\mathrm{O}_{2}$ but no $\mathrm{H}_{2} \mathrm{~S}$ in the deep ocean based on REE and redox-sensitive Ce signature in hydrothermal silicairon oxide sediments in open marine volcanogenic massive sulfide deposits. These studies considered Rare Earth Elements and Yttrium $(\mathrm{REE}+\mathrm{Y})$ data, particularly cerium (Ce) anomalies, as robust proxy for shallow-marine redox condition. In fact, Ce is considered a unique redox proxy because in addition to its trivalent oxidation state, like other REEs, it also exists in tetravalent oxidation state depending on the environmental oxidation condition. While in anoxic hydrosphere of Archean and Paleoproterozoic, the lack of trivalent Ce oxidation and absence of deep-ocean ferromanganese oxides led to high (positive) Ce concentration, in modern oxygenated deep-ocean oxidation of Ce to tetravalent state and availability of ferromanganese oxide (nodule and crust) result in negative Ce anomaly in sea water.

The Peninsular India, an ensemble constituting Archaean cratonic nuclei, orogenic belts, intrusive rocks and cover of extrusive volcanic and sedimentary rocks, records c. 3.0 Ga of Precambrian history (3.5$0.5 \mathrm{Ga}$; Fig. 1) and is considered a unique archive preserving the yet unexplored Precambrian events. Available geochronological data suggests cratonization of continental blocks viz. AravalliBundelkhand, Eastern and Western Dharwar, Bastar and Singhbhum and their amalgamation in Peninsular India at about 2.5 to $2.6 \mathrm{Ga}$ (Meert et al., 2010). On the cratonic basement, sedimentary basins evolved between late Archean and late Neoproterozoic, locally straddling the Precambrian-Cambrian boundary. Amongst them, most important are the unmetamorphosed and nearly undeformed Proterozoic cratonic basins, classically referred to as 'Purana Basins' in Indian stratigraphy. An attempt has been made to classify these basins (Meert et al., 2010; Meert and Pandit, 2015; Basu and Bickford, 2015) under three tiers viz. Paleo- to Mesoproterozoic, early Neoproterozoic and late Neoproterozoic, spanning an age range between 2 Ga and 542 Ma (Fig. 1). Availability of paleosol, chemical sediments e.g. carbonates, phosphorites, iron formations and sulfides (pyrite), sulfates (barite) etc. as integral parts of deformed late Archean and undeformed, unmetamorphosed Proterozoic basin fill packages have facilitated study of atmosphere and hydrosphere oxygenation history preserved in Indian geological records. Aim of present contribution is to collate and summarize available information from Precambrian basins of the Indian subcontinent.

\section{Atmospheric oxygenation record}

Paleosols are the best preserved direct record of atmospheric oxygen concentration (Rye and Holland, 1998). The study of Precambrian paleosol is seriously constrained by the extent and state of preservation. When a paleosol suffered significant erosion after weathering, false conclusions could be drawn from it (e.g., Rye and Holland 1998; Beukes et al., 2002; Murakami et al., 2011). However, better preserved records from the Archean-Paleoproterozoic paleosols allow the distinction between the oxic and reduced paleosols based on mobilization of soluble $\mathrm{Fe}^{+2}$ in the reduced paleosol profile (Rye and Holland, 1998) (e.g., 2.7 Ga Mount Roe paleosol, Macfarlane et al., 1994) . The $\mathrm{Fe}^{+2}$ on the other hand is retained in the form of $\mathrm{Fe}^{+3}$ in the upper part of the profile as laterite capping in case of the oxic paleosols (e.g., Hekpoort Paleosol, Beukes et al., 2002). The preGOE rise in atmospheric oxygenation has been reported from several >2.5 Ga paleosols (e.g Hokkalampi Paleosol from North Karelia, Finland: Marmo,1992). The oldest such report comes from the $\sim 3.4$ Ga Pilbara paleosol from Western Australia (Johnson et al., 2008). Johnson et al. (2008) described the paleosol as a typical top down alteration profile in pyrophyllite (locally chlorite) with hematite $\left(\mathrm{F}^{+3}\right)$ rich alteration zone at the upper part similar to lateritic profile of the 2.2 Ga Hekpoort paleosol from the Transvaal basin South Africa (Beukes et al. 2002). Mukhopadhyay et al. (2014) reported pre-GOE oxygenation from the $>3.0 \mathrm{Ga}$ old Keonjhar Paleosol in the Singhbhum craton, India. Pre-GOE oxygenation was also suggested by Crowe et al. (2013) from the $2.98 \mathrm{Ga}$ to 2.96 Nsuze paleosol in the Pongola basin South Africa. However, recent studies report uncertainties on such interpretation (e.g. Kasting, 2013; Kanzaki and Murakami, 2015; Rybacki et al., 2016). Other evidences come from: reduced paleoplacers from Archean deposits consisting of minerals such as pyrite and uraninite as detrital components (e.g., Grandstaff, 1974; Smith and Minter, 1980; Rasmussen and Buick 1999; Mukhopadhyay et al., 2012; 2016), secular trend in BIF abundance (Dymek and Klein, 1988; Beukes and Klein, 1992) and mass independent isotopic fractionation (MIF) in pre-GOE sulfides (Farquhar and Wing, 2013; Lyons et al., 2014). Luo et al. (2016), based on the model of Goldblatt et al. (2006), suggested that the great oxidation event or GOE witnessed a sharp rise in atmospheric oxygen concentration to more than $10^{-5} \mathrm{PAL}$ at around $2.33 \mathrm{Ga}$. A recent update of the model (Daines and Lenton, 2016) argued that a high level of atmospheric methane is necessary for the rapid rise of oxygen, which may or may not be the case in the early Paleoproterozoic (e.g., Zahnle et al., 2006; Olson et al., 2016). Major evidence in favour of oxygenation is the disappearance of massindependent sulphur isotopic fractionation at around 2.5 Ga (Kaufman et al., 2007). 


\section{Indian Record}

\section{Oxygen in atmosphere from Paleosols and fluvial deposits}

\section{From paleosols of the Singhbhum, Aravalli and Bastar Cratons and Meghalaya plateau:}

Reducing nature of early atmosphere is recorded in the uraniferous quartz pebble conglomerate (QPC) deposits from Mesoarchean Mahagiri-Keonjhar-Mankaharchua quartzites (Mukhopadhyay et al., 2014, 2016) and basal parts of the Meso-Neoarchean Dhanjori succession in the Singhbhum craton and the similar QPC deposits at the base of the Mesoarchean Bababudan Group of the western Dharwar craton (Srinivasan and Ojakangas, 1986). Precambrian paleosols are reported from the Singhbhum craton (Bandyopadhyay et al., 2010; Mukhopadhyay et al., 2014), Aravalli craton (Banerjee, 1996; Sreenivas et al., 2001), Central Indian Tectonic Zone (CITZ) (Mohanty and Nanda, 2016), Eastern Ghats (Dash et al., 1987; Sreenivas and Srinivasan, 1994) and Sonapahar sillimanite in Meghalaya, Northeastern India (Golani, 1989). Among these the first three occurrences have been studied in detail.

The Keonjhar Paleosol ranks among the oldest paleosols in the world (Fig. 2). The pre-GOE Mesoarchean oxic paleosol is developed over the 3.2 Ga Singhbhum Granite from the Singhbhum craton in eastern India (Mukhopadhyay et al., 2014). U-Pb zircon data suggest that the Keonjhar Paleosol was developed between 3.29 Ga and 3.02 Ga. The top part of the paleosol is not preserved. Mukhopadhyay et al. (2014) described typical top-down alteration zone with depletion of mobile elements ( $\mathrm{Na}, \mathrm{Ca}, \mathrm{Mg}, \mathrm{Cs}, \mathrm{Zn}, \mathrm{Ni}$ ) with respect to the basement granitoid. They also noted Fe-Mn depletion, HREE enrichment and true negative Ce-anomaly from the preserved profile of the Keonjhar Paleosol. The reduced paleoplacers of uraniferouspyritiferous QPCs of the overlying Keonjhar-Mahagiri Quartzite (Mukhopadhyay et al., 2016) suggest the return of the reducing atmosphere and support whiffs of oxygenation of early atmosphere prior to GOE (Fig. 2).

The Udaipur paleosol (Tulsi-Namla paleosol) (Banerjee, 1996; Sreenivas et al., 2001) developed in between the BGC and basal quartzite of the Paleoproterozoic Aravalli Supergroup preserves the topmost ferricrete capping of an oxic paleosol supposedly developed during 2.5 Ga and 2.1 Ga (Banerjee, 1996; Pandit et al., 2008; Wall et al., 2012; Fig. 1a, 2). However, from 1709 \pm 8 Ma age of a single detrital zircon grain from the Delwara Formation and 1.9-1.7 Ga detrital zircon ages from the Jhamarkotra Formation, McKenzie et al. (2013) questioned the early Paleoproterozoic age of the paleosol. The paleosol is exposed at the base of the Debari quartzite all over the Girwa (Udaipur) valley and has been metamorphosed in greenschist facies. The Udaipur paleosol at Tulsi-Namla section

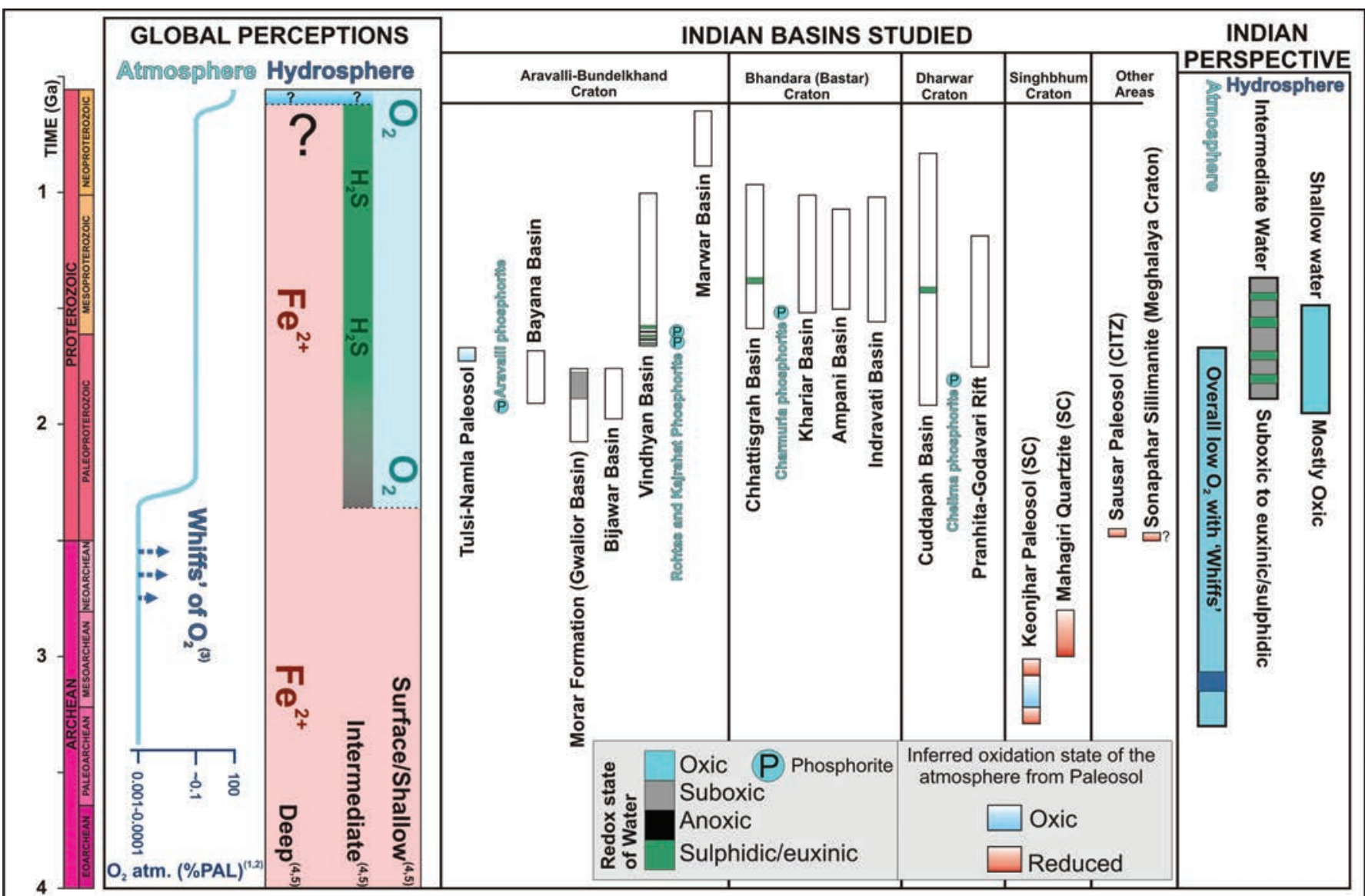

(1) Kump, 2008; (2) Planavsky et al., 2014; (3) Anber et al., 2007; (4) Pufahl and Hiatt, 2012; (5) Guilbaud et al., 2015.

Figure 2. A summary diagram showing current status on understanding of atmosphere and hydrosphere oxygenation and signatures from Indian Precambrian basins 
includes the most complete section with lower saprolite zone, followed upward by white mica zone capped by red ferricrete (Pandit et al., 2008; Wall et al., 2012). Pandit et al., (2008) described five zones within Tulsi-Namla paleosol. The Udaipur paleosol with complete profile of a typical laterite is comparable to the Hekpoort paleosol of South Africa (Beukes et al., 2002). However, Sreenivas et al. (2001) did not observe any ferricrete horizon in the profile they studied and they reported that the paleosol had been metamorphosed to kyanite grade that subsequently broke down to mica.

Mohanty and Nanda (2016) described 2.4 Ga paleosol from the base of the Sausar succession in the Central Indian Tectonic Zone (Fig. 1b). The paleosol horizon overlies the Tirodi Gneiss ( $>2500$ Ma) in Central India. These authors reported that the paleosol is depleted in HREE and shows flat Ce and Eu anomalies, low $\Sigma$ REE, and high $(\mathrm{La} / \mathrm{Yb})_{\mathrm{N}}$. Based on these proxies they suggested a reducing atmospheric condition during the formation of the paleosol. Based on available geochronologic data from the Sausar Group and Tirodi Gneiss, Mohanty and Nanda (2016) suggested the age of the paleosol to be in between $2.48 \mathrm{Ga}$ and $2.45 \mathrm{Ga}$. This age bracket is consistent with the reducing nature of atmosphere before the GOE at $2.33 \mathrm{Ga}$ (Luo et al., 2016).

Sillimanite-Corundum horizon of the Sonapahar sillimanite in Meghalaya, Northeastern India has been also interpreted as metamorphosed Precambrian bauxite deposit (Golani, 1989; Fig. 1b). From major and trace element data, Dash et al (1987) interpreted quartz-sillimanite-garnet bearing khondalites in Orissa as deeply weathered soil profile metamorphosed in upper amphibolite-granulite grade. Sreenivas and Srinivasan (1994) reviewed chemical compositions of more than 300 metapelites and khondalites from Dharwar craton, Aravalli craton and Eastern Ghats. They are of the opinion that most of the khondalites are metamorphosed paleosols, a view echoed long ago by Pascoe (1950).

The Indian Precambrian paleosols described so far are developed either on granitoids of $>3.1$ Ga or on granitoids of $\sim 2.5 \mathrm{Ga}$. With precise age determination these paleosols can provide well-constrained information on the evolution of oxygen in the atmosphere.

\section{Redox structure of hydrosphere}

\section{From basins of Bundelkhand, Bastar and Dharwar cratons}

Redox-sensitive chemical sedimentary rocks like iron formations, syngenetic pyrite deposits and authigenic sediments like carbonates and phosphorites along with sediments showing $\mathrm{Nd}$, Sr isotopic composition and REE distribution pattern of the ambient sea water provide authentic information about the Proterozoic hydrosphere including its oxidation state. Despite such a large scope of deciphering the paleohydrospheric condition, limited work has been done in India and studies remained largely restricted to a few basin fills. These include $\sim 1.7 \mathrm{Ga}$ old phosphorite deposit from the Aravalli craton (McKenzie et al, 2013), 1.45 Ga old iron formation from the Gwalior basin of the Bundelkhand craton, sulfides (pyrite) from the Vindhyan and Chhattisgarh basins of Bundelkhand and Bastar cratons and sulphates (barite) from the Cuddapah basin of the Dharwar craton (Fig.1a,b). The stratigraphic units include phosphorite in the middle part of the Aravalli Supergroup, Rajasthan; ferruginous, aluminous phosphorites in the Bijawar Group, Banded Iron Formation (BIF) from the Morar Formation of the Gwalior Group; authigenic pyrite deposits from the Bijoygarh Shale Formation of the Vindhyan Supergroup; Charmuria Limestone Formation of the Chhattisgarh Supergroup in the central India. Barite-pyrite deposit from the Cumbum Shale Formation of the Cuddapah Supergroup is also included. Geochemical proxy element analysis from the argillaceous intervals of the Vindhyan Supergroup (Singh et al., 2018) indicating hydrosphere redox structure also reported.

\section{Basin wide Chronology}

Mafic dykes in the Bundelkhand granite dated by Rb-Sr and K-Ar methods suggest 1775-1790 Ma and 1800 Ma ages for these rocks (cf. Ramakrishnan and Vaidyanadhan, 2008; Pradhan et al., 2012). Absar et al. (2005, 2008, 2010) dated carbonate rocks and banded iron formations (BIF) from the upper part of the Morar Formation, Gwalior basin with $\mathrm{Pb}-\mathrm{Pb}$ isotopic technique (1914 \pm 120 Ma and 1866 \pm 250 Ma). In recent time, Paul (2017) dated volcanic rocks present at the transition zone between the Par Formation and Morar Formation using Sm-Nd systematic (1787 \pm $60 \mathrm{Ma}$ ). This age data helped in constraining late Paleoproterozoic depositional age of the sediments of the Gwalior basin including the Morar Formation.

$\mathrm{Pb}-\mathrm{Pb}$ dates of stromatolitic limestones from the Kajrahat and Rohtas Formations of the Vindhyan Supergroup are 1627 $\pm 76 \mathrm{Ma}$ (Banerjee and Russell, 1993), $1721 \pm 90$ Ma (Sarangi et al, 2004; Ray, 2006), $1601 \pm 130$ Ma (Ray et al., 2003) and $1599 \pm 48 \mathrm{Ma}$ (Sarangi et al, 2004).. The zircon U-Pb dates (both conventional and SHRIMP techniques) of $1630.7 \pm 0.4 \mathrm{Ma}$ (Ray et al. 2002) and 1628 \pm 0.8 Ma (Rasmussen et al. 2002) of the Porcellanite Formation, occurring between the Kajrahat and Rohtas Formations of the Semri Group of the Lower Vindhyan are consistent with the $\mathrm{Pb}-\mathrm{Pb}$ dates determined independently. A bedded tuff present within the Rampur Shale Formation of the Lower Vindhyan is also dated as $1599 \pm 8 \mathrm{Ma}$ by U-Pb methods. Palaeomagnetic studies and a LA-ICPMS U-Pb detrital zircon age of 1020 Ma from the Upper Bhander sandstone (Malone et al. 2008) brackets the upper limit of the Vindhyan Superegroup.. Hence, the syn-sedimentary pyrites in the Bijoygarh Shale, discussed in this paper, suggest a Mesoproterozoic age of 1.6 Ga and $1.0 \mathrm{G}$.

Das et al. (2009) calculated $\sim 1455 \pm 47$ Ma age (EPMA U-Th$\mathrm{Pb}$ dates of monazite grains from bedded tuff) for the basal part of the Chhattisgarh succession. The U-Pb SHRIMP date on zircon from the tuff layers in the uppermost Tarenga Shale provides an age range of 990-1020 Ma (Patranabis Deb et al. 2007). Bounded between the two well-dated horizons, the pyritiferous Charmuria Limestone undoubtedly indicates a Mesoproterozoic age.

The lower part of the Cuddapah basin provides ages between $1817 \pm 24$ Ma (Rb-Sr date of the Pulivendla mafic sill emplaced into the Tadpatri shales: Bhaskar Rao et al. 1995) and $1756 \pm 29 \mathrm{Ma}$ $(\mathrm{Pb}-\mathrm{Pb}$ age of uranium bearing stromatolitic dolomite from the Vempalle and Tadpatri Formations (Zachariah et al. 1999). The ${ }^{40} \mathrm{Ar}-$ ${ }^{39} \mathrm{Ar}$ age of $1418 \pm 8 \mathrm{Ma}$ of lamproite dyke intrusion within the Cumbum shale (Chalapathi Rao et al. 1999) marks the termination of the Cuddapah sedimentation. Although both $\mathrm{Rb}-\mathrm{Sr}$ and $\mathrm{Ar}-\mathrm{Ar}$ ages are prone to resetting, the age ranges suggest that both the pyrite and barite samples of the Cumbum shale, studied by Sarkar et al. (2009), belong to Mesoproterozoic age between 1.8 Ga and $1.4 \mathrm{Ga}$. 


\section{Signature from Iron Formation of the Morar Group, Gwalior basin}

The Rare Earth Element (REE) distribution patterns shown by the iron formations have been extensively used to interpret chemistry of the ocean basins. This is because many temporal trends in the REE datasets reflect fluctuations in the marine redox conditions. With this understanding, Paul (2017) carried out REE analyses of BIF from late Paleoproterozoic Morar Formation of the Gwalior Group, central India. Small negative to positive Ce anomaly observed within Gwalior BIFs (Fig. 3) is comparable with Ce anomalies reported from sulfidic

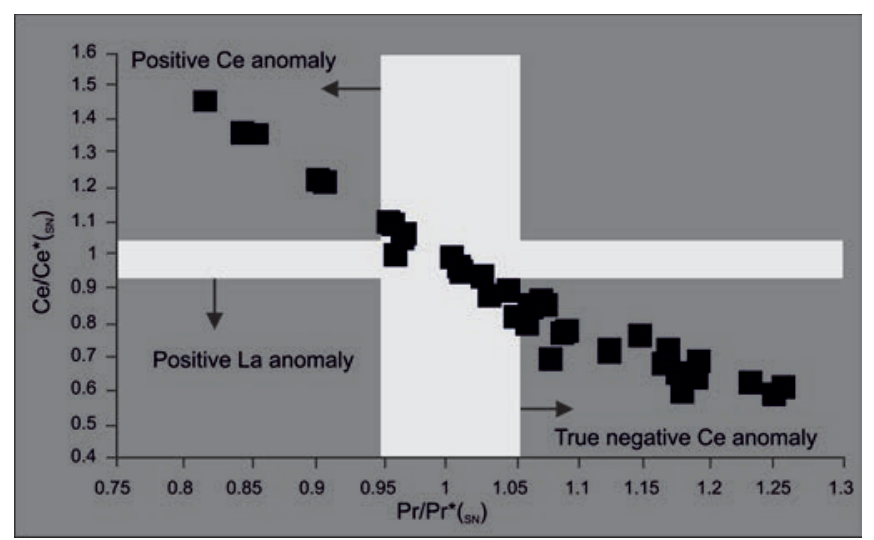

Figure 3. $\mathrm{Ce} / \mathrm{Ce} e_{(S N)}^{*}$ vs. $\mathrm{Pr} / \mathrm{Pr}^{*}{ }_{(S N)}$ plot from Gwalior BIF. Note Ce anomaly ranging from small negative to small positive. True negative Ce anomalies are defined by $\mathrm{Ce} / \mathrm{Ce}^{*}{ }_{S N}$ (after Bau and Dulski, 1996).

waters of the Black Sea. However, rare presence of sulfide minerals in association of the dominant hematite mineralogy of BIF helped Paul (2017) to rule out the possibility of anoxic, sulfidic environment in then deeper-waters of the Gwalior sea. Instead, a sub-oxic condition (dissolved $\mathrm{O}_{2}$ below $\sim 0.2 \mu \mathrm{mol} /$ liter and no dissolved sulfide) is inferred that allowed neither Mn oxidation nor Ce sequestration. The sub-oxic ocean model also got support from i) unequivocal $\mathrm{La} / \mathrm{Nd}$ value of $>1$, ii) MREE enrichment similar to modern open oceans and marginal seas, and iii) small negative to positive Ce anomalies in Gwalior BIF. This pattern is not like Archean anoxic oceans (without any anomaly) or modern oxygenated marine water (with strong negative Ce anomaly). A clear dominance of positive $\mathrm{Eu}_{\mathrm{SN}}$ anomalies in Post-Archean Australian Shale (PAAS) normalized REE pattern of Gwalior BIF bears clear signature of higher temperature and reduced hydrothermal solution influence in shallow subtidal waters of the Gwalior Sea. These differences become obvious when compared with modern sea floor iron oxyhydroxide precipitates from reduced high temperature hydrothermal fluids. This interpretation has to be seen in the context of mass balance estimates for REEs in the oceans based on Nd isotopic composition and on Eu anomalies. Derry and Jacobsen (1990) have shown large variations in the REE distribution patterns in similar sediments and inferred the nonconservative behavior of Eu during mixing of hydrothermal waters with ambient water.

\section{Signatures from sulfides and sulfates}

The fractionation of sulphur between sulfate $\left(\mathrm{SO}_{4}{ }^{\circ}\right)$ and sulfide
$\left(\mathrm{H}_{2} \mathrm{~S}\right)$ species in oceans is driven by bacterial sulphate reduction (BSR). Sulfide produced by BSR is either recycled as sulfate or combines with available iron to form pyrite $\left(\mathrm{FeS}_{2}\right)$. Burial of sedimentary pyrites (and organic carbon) eventually controls oxygen in an ocean-atmosphere system (Berner, 1984; Bottrell and Newton, 2006). BSR preferentially fractionates ${ }^{32} \mathrm{~S}$ in sulfides, making the remaining sulfates enriched in ${ }^{34} \mathrm{~S}$. Since the amount of reduction depends both on the redox state at the sediment-water interface and the supply of sulfate in the water column, the sulphur isotope compositions $\left(\delta^{34} S\right)$ of sedimentary sulfides are used as potential tracer of ocean chemistry. With this understanding, Sarkar et al (2010) determined $\delta^{34}$ Svalues for authigenic pyrites from the Bijoygarh Shale of Vindhyan Supergroup, Charmuria Limestone of Chhattisgarh Supergroup, Cumbum Shale and Narji Limestone of Cuddapah Supergroup and barite from the Pullampet Formation (Mangampeta mine) of the Cuddapah Supergroup (Fig.1).

Moderate to very heavy $\delta^{34} \mathrm{~S}$ values are recorded from pyrites in these basins with values ranging from 8.1 to $38.8 \%$. In fact, a collation of $\delta^{34} \mathrm{~S}$ values generated from pyrites collected from Vindhyan and Chhattisgarh basins (Sinha et al. 2001; Guha, 1971; Sarkar et al., 2010) reveals mean $\delta^{34} S$ values of Chhattisgarh and Vindhyan pyrites as $26.3 \pm 0.9 \%$ o $(n=12)$ and $25.5 \pm 8.7 \%$ o $(n=42)$, respectively. Limited data from syn-sedimentary Cuddapah pyrites show a mean $\delta^{34} \mathrm{~S}$ value of $28.3 \pm 11.8 \%$ o $(\mathrm{n}=6)$. When all available data are considered, pyrites from the Vindhyan and Chhattisgarh basins record ${ }^{34} \mathrm{~S}$ enrichment, ranging between $4.5 \%$ and $40.7 \%$, irrespective of the nature of pyrite (framboidal, euhedral or laminated). No pyrite from these basins has registered moderate to extreme negative $\delta^{34} \mathrm{~S}$ values as observed in most sedimentary pyrites of Phanerozoic age (Strauss, 1999; Canfield \& Raiswell, 1999; Canfield, 2004 and references therein). The $\delta^{34} \mathrm{~S}$ values as high as $\sim 40 \%$ are closer to or even higher than the known $\delta^{34}$ S value of Proterozoic marine sulfates (Strauss, 1997; Kah et al, 2001; Gellatly and Lyons, 2005; Canfield, 2004). $\delta^{34} S$ values from marine sulfate i.e the Cuddapah barite show a narrow range i.e 41.8 to $45.5 \%$ (cf. Clark et al, 2004) with a mean value of $+42.3 \%$ (Sarkar et al., 2010). These values are not only enriched by about $10-15 \%$ more than the contemporary (Mesoproterozoic) marine sulfate (Kah et al, 2001, 2004; Gellatly and Lyons, 2005), but also have exceptionally small variation compared to other Proterozoic barite deposits of the world (Clark et al., 2004; Strauss, 1999; Kah et al., 2001; Kah et al, 2004; Gellatly \& Lyons, 2005). The maximum pyrite $\delta^{34} S$ value of $\sim+40 \%$ is not very different from this sulphate value.

From geochemical model involving kinetic isotope effect during the $\mathrm{SO}_{4}={ }_{4} \leftrightarrow \mathrm{S}^{=}$reduction and $\mathrm{SO}^{=}{ }_{4} / \mathrm{H}_{2} \mathrm{~S}$ ratio of different geochemical systems that are either open or closed with respect to $\mathrm{SO}_{4}^{=}$or $\mathrm{H}_{2} \mathrm{~S}$, Sarkar et al (2010) concluded that very high $\delta^{34} \mathrm{~S}$ values (>35 \%) in both Chhattisgarh and Cuddapah basins are result of pyrite removal/ burial at a rate much faster than the rate of sulfate reduction (cf. Ohmoto \& Rye, 1979; Strauss \& Schieber, 1990). The data provide evidence in support of a hypothesized global Proterozoic sulfidic anoxic ocean where very low concentrations of marine sulfate, bacterially reduced in closed systems, produced $\delta^{34} \mathrm{~S}$ values in pyrites similar to or even heavier than marine sulfate. The comparatively lower $\delta^{34} \mathrm{~S}$ values in Vindhyan pyrites is interpreted as result of semi-confined marine depositional environment where $\mathrm{SO}^{=}{ }_{4}$ flux was still higher (though limited) compared to the other two basins. 


\section{Signature from argillaceous sedimentary rocks}

Singh et al (2018) carried out redox-sensitive elements (Mo, Cr) and primary organic productivity (total organic carbon; TOC) analysis from argillaceous intervals of the Vindhyan succession to provide clue on redox conditions in the Proterozoic ocean. Their analytical data suggested that the hydrosphere during Vindhyan sedimentation developed euxinic deep water only during deposition of Arangi, Rampur and Bijoygarh black shale. They called the condition as anoxic but certainly not completely euxinic during the deposition of Koldaha and Rewa shale. Low concentration of Mo and Cr within the argillaceous intervals helped these authors to conclude that the Vindhyan Sea behaved as a moderate Mo, depleted Cr reservoir. The consistent low concentration of $\mathrm{Cr}$ within the Vindhyan shales is attributed to insignificant terrestrial supply of $\mathrm{Cr}(\mathrm{Cr}$ (VI)) due to very low oxygen concentration in the contemporary atmosphere.

\section{Signature from phosphatic rocks}

Precambrian phosphorites are believed to have commonly formed in the shallow marine setting through phosphogenesis i.e as authigenic precipitates having the mineralogy of francolite or carbonate fluorapatite (Banerjee et.al. 1980). Francolite shows extensive substitution of its components and is expressed as $\mathrm{Ca}_{10 \text {-a- }} \mathrm{Na}_{\mathrm{a}}, \mathrm{Mg}_{\mathrm{b}}$ $\left(\mathrm{PO}_{4}\right)_{6 \mathrm{x}-\mathrm{y}-\mathrm{z}}\left(\mathrm{CO}_{3}\right)_{\mathrm{xy}-\mathrm{z}}\left(\mathrm{SO}_{4}\right) \mathrm{F}_{2}$. Processes like authigenesis; hydrodynamic reworking in the shallow marine realm and organic activity in the sunlit shallow shores produce phosphate rich layers, frequently associated with the cyanobacterial mats. Phosphorus is removed from the nutrient rich surface waters by cyanobacteria and authigenetically converted to carbonate fluorapatite through mediation of a series of microbially induced reactions in the bottom and pore waters (Schidlowski et al, 1985; Banerjee and Klemm, 1985, Banerjee et al.1986): The pore waters tend to become supersaturated with respect to calcium phosphate leading to precipitation of carbonate fluorapatite in fairly anoxic environment, virtually cut off from the oxic waters of the basin. Chert and black shales are common associated rocks in such depositional settings. Recently, it was observed (Reinhart et al, (2013) that despite more limited extent of euxinia that was previously envisaged, life in the Proterozoic ocean (which in turn provide the organic matter and created anoxia) was heavily influenced by the presence of sulfide in the water column.

Phosphorite did not form in the Archean and its appearance in the Paleoproterozoic in many parts of the world is believed to coincide with the GOE. However, the early Paleoproterozoic status of some deposits has been questioned in view of recent detrital zircon ages derived from the arenite units underlying the phosphate deposit. One such example is India's largest phosphorite deposit in the Aravalli rocks of Udaipur region in Rajasthan, which was erroneously bracketed under 2.2- 2.0 Ga time frame because of its inappropriate correlation with anomalously $\delta^{13} \mathrm{C}$ enriched phosphate-free carbonate that records the Lomagundi-Jatuli event. Taking into consideration the presence of a large population of 1.9-1.7 Ga detrital zircon grains in underlying arenite, McKenzie et al (2013) refuted the $2.2-2.0$ time frame for the phosphatic carbonate and argued in favor of a late Paleoproterozoic $(\sim 1.7 \mathrm{Ga})$ depositional age. Support for late Paleoproterozoic age also comes from the $\mathrm{Pb}$ isotope age of pyrite from rocks of similar stratigraphic disposition (Deb and Thorpe, 2004). Recent geochronologic data suggest that the phosphogenic event in the Aravalli belongs to the tail end of the oxygenation event which continued into the early phase of the boring billion and therefore does not strictly coincide with the GOE as postulated earlier (Papineau, 2010, Pufahl, 2010). It possibly indicates relatively oxygenated (suboxic?) shallow marine condition through late Paleoproterozoic to early Mesoproterozoic as documented by intimate association of non-pelletal, dense authigenic phosphorite formed through the cyanobacterial interventions. Occurrence of phosphatic laminae and beds in the Rohtas and Kajrahat limestones of Vindhyan basin in the Son valley, Gangolihat Dolomite in the Kumaun Himalaya, Chelima area of the Cuddapah Supergroup and Charmuria Formation in the Chhattisgarh Supergroup (Banerjee, 1985) justify this contention. Also, Fe-rich aluminous phosphorites of putative Paleoproterozoic age occurring in the Bijawars of central India (Banerjee et al, 1982) is modeled in terms of extensive weathering related origin. Such shallow marine phosphorites and weathering profile related phosphorites are in stark contrast to upwelling related Phanerozoic phosphorites formed in the deeper part of shelf. This difference most likely reflects the dissimilarity in the oxygenation state of the sea floor (Nelson et al., 2010, Reinhart et al. 2013) between the Proterozoic and Phanerozoic times.

\section{Discussion}

From convergence of geochemical evidence, it is suggested that the unidirectional and significant oxygenation of the Earth surface occurred in two major steps; first step at 2.33 Ga (Luo et al., 2016) and the second step between $800 \mathrm{Ma}$ and $541 \mathrm{Ma}$ (Scott et al., 2008; Tang et al., 2016). The time period encompassing late Paleoproterozoic and Mesoproterozoic, remains the most intriguing time slot and is debated period in the Earth history principally because of i) first appearance of eukaryotes, though in low diversity (Blumenberg et al., 2012; Reinhard et al., 2013) and ii) claim of very low oxygen concentration in shallow seawaters (Tang et al., 2016). Within this broad framework, reports on whiffs of oxygenation keep coming from Archean records. Indian geology is no exception; the 3.29-3.02 Ga old Keonjhar paleosol in the Singbhum craton holds signature of Paleo- and Meso-Archean oxygenation whiffs. Short-lived character of these whiffs and return of reduced atmospheric conditions can be envisaged from occurrence of reduced uraniferous-pyritiferous paleoplacers in arenites overlying the Keonjhar paleosol or report of 2.48-2.45 Ga old reduced paleosol from the Sausar succession. The Sonapahar sillimanite has not been studied in detail.

Available geochemical results from marine sedimentary pile, both carbonates and argillites belonging to late PaleoproterozoicMesoproterozoic basins all over the Indian sub-continent are not sufficiently exhaustive to provide definitive answers to various mysteries of the redox conditions in the hydrosphere. While BIFs from late Paleoproterozoic Morar Formation register a suboxic marine condition from unequivocal La/Nd value $>1$, MREE enrichment and small negative to positive Ce anomaly, moderate to very heavy $\delta^{34} \mathrm{~S}$ values from sulfides (pyrite), close to or even higher than the reported $\delta^{34} \mathrm{~S}$ value of Proterozoic marine sulfate (barite), present in Mesoproterozoic Bijoygarh Shale of the Vindhyan Supergroup and Charmuria Limestone of the Chhattisgarh Supergroup support the sulfidic and anoxic deep ocean model, similar to the 'Canfield Ocean' model (Logan et al., 1995; Hurtgen et al., 2002; Canfield, 2004). Argillaceous sediments from the Vindhyan Supergroup, analyzed for redox-sensitive elements and total organic carbon (TOC), support the anoxic deep ocean model throughout the Mesoproterozoic. The 
study, however, refuted the idea of persistent euxinic deep ocean model. Considering sulfidic condition as the major cause behind persistent ocean euxinicity, Singh et al. (2018) inferred that low Mo and low Mo/TOC values in the argillaceous intervals are signals for dominant non-sulfidic deep ocean condition in course of Vindhyan sedimentation history. In contrast, a relatively oxygenated shallow marine condition possibly prevailed through late Paleoproterozoic and Mesoproterozoic times as suggested from close association of non-pelletal, dense, authigenic, phosphorites with cyanobacterial colony in many late Paleoproterozoic - early Mesoproterozoic Indian basins. This conjecture is likely to be over-simplification of the complex depositional processes in the backdrop of recent chromium isotope study on shallow marine ironstones (Planavsky et al., 2014) that estimates below $0.2 \mu \mathrm{M}$ dissolved oxygen (i.e $0.1 \%$ of PAL) in mid-Proterozoic shallow marine environment.

The discussion here highlights the fact that the Proterozoic chemical sedimentary rocks in the Indian subcontinent need to be studied in more details for making definitive interpretations of the past atmosphere and hydrosphere and make significant contribution to our understanding of the onset of oxygenation event in the Earth history.

\section{Acknowledgement}

JM acknowledges FRPDF grant for his research from Presidency University, Kolkata. PPC and PP acknowledges UGC major project grant for carrying out work at the Gwalior basin.

\section{References}

Absar, N., 2005, Geology and Geochemistry of Paleoproterozoic Gwalior Group Sediments, Bundelkhand Craton, Central India: Implications for Provenance, Depositional Environment, Tectonic Setting and Evolutionary Trend of Upper Continental Crust. Unpublished Ph.D. Thesis. Aligarh Muslim University, Aligarh, India, 189p.

Absar, N., Raza, M., Roy, M., Naqvi, S. M., and Roy, A. K., 2009, Composition and weathering conditions of Paleoproterozoic upper crust of Bundelkhand Craton, Central India: Records from geochemistry of clastic sediments of 1.9 Ga Gwalior Group. Precambrian Research, v.168, pp.313-329.

Absar, N., Raja, M., Roy, M., Pandey, B. K., Roy, A. K., Krishna, V., and Pandey, U. K., 2010, Pr, Sr, and Isotope systematics of chemical sedimentation of Paleoproterozoic Gwalior Group, Bundelkhand Craton, Central India: Implication for age and provenance. Exploration and Research for Atomic Minerals, v.20, pp.73-96.

Anbar, A. D., Duan, Y., Lyons, T. W., Arnold, G. L., Kendall, B., Creaser, R. A., Kaufman A. J., Gordon, G. W., Scott, C., Garvin, J., and Buick, R., 2007, A whiff of oxygen before the Great Oxidation Event? Science, v. 317, pp. 903-1906.

Arnold, G. L., Anbar, A. D., Barling, J., and Lyons, T. W. 2004, Molybdenum Isotope Evidence for widespread anoxia in MidProterozoic oceans. Science, v.304, pp.87-90.

Bandyopadhyay, P. C., Eriksson, P. G., and Roberts, R. J., 2010, A verticpaleosol at the Archean-Proterozoic contact from the Singhbhum-Orissa craton, eastern India. Precambrian Research, v.177, pp.277-290.

Banerjee, D.M., Basu, P.C. and Srivastava, N., 1980, Petrology, Mineralogy, Geochemistry and Origin of the Precambrian Aravallian Phosphorite Deposits of Udaipur and Jhabua, India.
Economic Geology, v.75, pp.1181-1199.

Banerjee, D. M., Khan, M. W.Y., Srivastava, N., and Saigal, G. C., 1982, Precambrian phosphorites in the Bijawar rocks of HirapurBassia area, Sagar District, Madhya Pradesh, India, Mineralium Deposita, vol. 17, pp. 349-362.

Banerjee, D.M., 1985, Proterozoic stratigraphy of the Indian Platform and the Concept of Phosphogenic Cycles- A Proposal. Geological Survey of Finland Bulletin, v.331, pp.73-89.

Banerjee, D. M., Klemm, U., 1985, Organo-geochemical stud-ies of Proterozoic stromatolitic phosphorites and the inter-columnar dolomite from the Aravalli Group, India. Journal of Geological Society of India, vol. 26, pp. 245-254.

Banerjee, D. M., Schidlowski, M., Arneth, J. D., 1986, Genesis of upper Proterozoic-Cambrian phosphorite deposits of India: isotopic inferences from carbonate fluorapatite, carbonate and organic carbon. Precambrian Research. Vol, 33, pp. 239-253.

Banerjee, D. M. and Russell. J., 1993, Pb/Pb dating of Vindhyan stromatolites and a comparison with stromatolitic dates from other Proterozoic terrains. Group discussion on the Vindhyans, Jadavpur University, 29.

Banerjee, D. M., 1996, A Lower Proterozoic paleosol at BGC-Aravalli boundary in south-central Rajasthan India, Journal of the Geological Society of India, v. 48, pp. 277-288.

Basu, A., and Bickford, M. E., 2015, Alternate Perspective on the Opening and Closing of the Intracratonic Purana Basins in Peninsular India. Journal Geological Society of India, Vol.85, pp.5-25.

Bau, M., Dulski, P., 1996. Distribution of yttrium and rare-earth elements in the Penge and Kuruman iron formations, Transvaal Supergroup, South Africa. Precambrian Research 79, 37-55.

Berner, R. A., 1984, Sedimentary pyrite formation: An update. Geochimica et Cosmochimica Acta vol. 48, pp. 605-615.

Beukes, N.J., and Klein, C., 1992, Models for Iron-Formation Deposition. In: Schopf, J.W., Klein, C., (Eds.), The Proterozoic biosphere: a multidisciplinary study. Cambridge University Press, Cambridge, pp.147-151.

Beukes, N. J., Dorland, H., Gutzmer, J., Nedachi, M., and Ohmoto, H., 2002, Tropical laterites, life on land, and the history of atmospheric oxygen in the Paleoproterozoic. Geology, v.30, pp. 491-94.

Bhaskarrao, Y. J., Pantulu, G.V.C., Damodarareddy, V. and G Opalan, K., 1995, Time Of Early Sedimentation And volcanism in the Proterozoic cuddapah basin, South India: Evidence From The Rb-Sr Age Of The Pulivendla Maûc Sill. Geological Society of India Memoir 33, pp. 329-38.

Blumenberg, M., Thiel, V., Riegel, W., Kah, L.C., and Reitner, J., 2012, Black shale formation by microbial mats lacking steraneproducing eukaryotes, late Mesoproterozoic (1.1 Ga) Taoudeni Basin, Mauritania. Precambrian Research, v.196-197, pp. 113127.

Bottrell, S. H., and Newton, R. J., 2006, Reconstruction of changes in global sulfur cycling from marinesulfate isotopes. Earth-Science Reviews, vol.75, pp.59- 83.

Brocks, J. J., Love, G. D., Summons, R. E., Knoll, A. H., Logan, G. A., and Bowden, S. A. 2005, Biomarker evidence for green and purple sulphur bacteria in a stratiûed Palaeoproterozoic sea, Nature, v. 437, pp.866-70.

Canfield, D. E., 1998, A New Model for Proterozoic ocean chemistry, Nature, v.396, pp. 450-3.

Canfield, D. E., and Raiswell, R., 1999, The evolution of the sulphur cycle. American Journal of Science, v. 299, pp.697-723.

Canfield, D. E. 2004, The evolution of the earth-surface sulphur reservoir. American Journal of Science, v.304, pp.839-61.

Chalapathi Rao, N. V., Miller, J. A., Gibson, S. A., Pyle, D. M., and 
Madhavan, V., 1999, Precise 40Ar/39Ar age determinations of the Kotakonda kimberlite and Chelima lamproite, India: Implication to the timing of mafic dyke swarm emplacement in the eastern Dharwar craton. Journal Geological Society of India, v. 53, pp. 425-432.

Clark, S. H. B., Pooleb, F. G., and Wang, Z. 2004, Comparison of some sediment-hosted, stratiform barite deposits in China, the United States, and India. Ore Geology Review, v. 24, pp.85-101.

Crowe, S. A., Døssing, L. N., Beukes, N. J., Bau, M., Kruger, S. J., Frei, R., and Canfield, D.E., 2013, Atmospheric oxygenation three billion years ago, Nature, v. 501, pp. 535-538.

Daines, J. S., and Lenton, T. M., 2016, The effect of widespread early aerobic marine ecosystems on methane cycling and the Great Oxidation. Earth and Planetary Science Letters. vol.434, pp, 42-5.

Dalziel, I. W. D., 1997, Overview: Neoproterozoic-Paleozoic geography and tectonics: review, hypothesis and environmental speculations. Geological Society of America Bulletin, v.109, pp.16-42.

Dash, B., Sahu, K. N. and Bowes, D. R. 1987, Geochemistry and original nature of Precambrian khondalites in the Eastern Ghats, Orissa, India. Trtns R Society Edinburgh Earth science, vol. 78, pp.115-27.

Das, K., Yokoyama, K., Chakraborty, P. P., and Sarkar, A., 2009, Basal tuffs and contemporaneity of the Chattisgarh and Khariar Basins based on new dates and geochemistry. The Journal of Geology, v.117, pp. 88-102.

Deb, M., and Thorpe, R. L., 2004, Geochronological constraints in the Precambrian geology of Rajasthan and their metallogenic implications. In:Debm and Goodfellow W. D., $\quad$ (Eds.), Sediment-Hosted Pb-Zn Sulphide Deposits. Narosa Publication, New Delhi, pp. 246-263.

Derry, L. A and Jacobse, S. B., 1990, The chemical evolution of Precambrian seawater: Evidence from REEs in banded iron formations. Geochimica et Cosmochimica Acta vol. 54, pp. 29652977.

Des Marais, D. J., 2000, When did photosynthesis emerge on Earth? Science, v. 289(5485), pp.1703-1705.

Dymek, R.F., and Klein, C., 1988, Chemistry, petrology and origin of banded iron- formation lithologies from the 3800 ma Isua supracrustal belt, west Greenland. Precambrian Research, V. 39, pp. 247-302.

Farquhar, J., and Wing, B.A., 2003, Multiple sulfur isotopes and the evolution of theatmosphere. Earth Planetary Science Letters, v. 21, pp.1-13.

Farquhar, J., Zerkle A. L., Bekker A., 2011, Geological constraints on the origin of oxygenic photosynthesis. Photosynthesis research, v. 107-1, pp.11-36.

Gellatly, A.M., and Lyons, T.W., 2005, Trace sulfate in mid Proterozoic carbonates and the sulfur isotope record of biospheric evolution. Geochimica et Cosmochimica Acta, v.69, pp.381329.

Golani, P.R., 1989, Sillimanite-corundum deposits of Sonapahar, Meghalaya, India: a metamorphosed Precambrian paleosol. Precambrian Research, v.43, pp.175-189.

Goldblatt, C., Lenton,T. M., Watson, A. J., 2006, Bistability of atmospheric oxygen and the Great Oxidation. Nature. Vol. 443, pp. 683-686.

Gradstein, F.M., Ogg, J.G., Schmitz, M.D., and Ogg, G.M., 2012, The Geological Time Scale 2012 ( $1^{\text {st }}$ edition). Amsterdam, Elsevier, 2 vols., 1144 p.

Grandstaff, D.E., 1974, Microprobe Analyses of Uranium and Thorium in Uraninite from the Witwatersrand, South Africa, and Blind River, Ontario, Canada. Transaction Geological Society of South Africa, v.77, pp.291-294.
Guha, J. 1971, Sulphur isotope study of the pyrite deposit of Amjhore, Shahbad district, Bihar. India. Economic Geology, v. 66, pp.32630 .

Guilbaud, R., Poulton, S. W., Butterfield, N. J., Zhu, M., and ShieldZhou, G.A., 2015, A global transition to ferruginous in the early Neoproterozoic oceans. Nature Geoscience, vol. 8, pp. 466-470.

Hoffman, P.F., Kaufman, A.J., Halverson, G.P., and Schrag, D. P., 1998, A Neoproterozoic snowball Earth. Science, v. 281, pp.1342-1346.

Holland, H.D., 1984, The Chemical Evolution of the Atmosphere and Oceans. Princeton University Press.

Holland, H. D., and Beukes, N. J., 1990, A paleoweathering profile from Griqualand West, South Africa: evidence for a dramatic rise in atmospheric oxygen between 2.2 and 1.9 by bp. American Journal of Science, v. 290-A, pp.1-34.

Hurtgen, M.T., Arthur, M.A., Suits, N.S., and Kaufmann, A. J., 2002, The sulphur isotopic composition of Neoproterozoic seawater sulphate: implications for a snowball earth? Earthand Planetary Science Letters, v. 203, pp.413-29.

Johnson, I. J., Watanabe, Y., Yamaguchi, K., Hamasaki, H., and Ohmoto, H., 2008, Discovery of the oldest ( 3.4Ga) lateritic paleosols in the Pilbara Craton Western Australia. Geological Society of America, Abstracts N. 40, p.143.

Kah, L. C., Lyons, T. W. and Chesley, J. T. 2001, Geochemistry of a 1.2 Gacarbonate evaporite succession, Northern Bafûn Islands: Implications for Mesoproterozoic marine evolution. Precambrian Research, v.111, pp.203-34.

Kah, L. C., Lyons, T. W., and Frank, T. D., 2004, Low marine sulphate and protracted oxygenation of the Proterozoic biosphere. Nature, v. 431, pp.834-38.

Kanzaki, Y., Murakami T., 2015, Estimates of atmospheric CO2 in the Neoarchean-Paleoproterozoic from paleosols. Geochimica et Cosmochimica Acta v.159, pp.190-219.

Karhu, J.A., Holland, H.D., 1996, Carbon isotopes and the rise of atmospheric oxygen Geology, v.24, pp. 867-870.

Kasting, J. F., 2013, What caused the rise of atmospheric O2? Chemical Geology, vol. 362, pp.13-25.

Kaufman, A.J., Johnston, D.T., Farquhar, J., Masterson, A., Lyons, T.W., Bates, S., Anbar A. D., Arnold, G.L., Garvin, J., and Buick, R., 2007, Late Archean biospheric oxygenation and atmospheric evolution. Science, v. 317, pp.1900-1903.

Knoll, A. H., 1994, Proterozoic and Early Cambrian protists: Evidence for accelerating evolutionary tempo. Proceeding National Academic Science USA., v. 91, pp. 6743-6750

Kump, L.R., 2008, The rise of atmospheric oxygen. Nature, v. 451, pp.277-278.

Logan, G.A., Hayes, J.M., Hieshima, G.B., and Summons, R.E. 1995, Terminal Proterozoic reorganization of biogeochemical cycles. Nature, v. 376, pp.53-6.

Luo, G., Ono, S., Beukes, N. J., Wang, D. T., Xie, S., and Summons, R. E., 2016, Rapid oxygenation of Earth's atmosphere 2.33 billion years ago. Science Advances, v.13 (2,5), pp.1-9.

Lyons, T.W., Reinhard, C.T., and Planavsky, N.J., 2014, The rise of oxygen in Earth's early ocean and atmosphere. Nature, v. 506, pp. 307-315.

Macfarlane, A. W., Danielson, A., and Holland, H. D., 1994, Geology and major and trace element chemistry of late Archean weathering profiles in the Fortescue Group, Western Australia: implications for atmospheric PO2. Precambrian Research, v.65, pp.297-317.

McKenzie, R.N., Hughes, N.C., Myrow, P.M, Banerjee, D.M., Deb, M., and Planavasky, N.J., 2013, New age constraints for the Proterozoic-Delhi successions of India and their implications. Precambrian Research, v.238, pp.120-128. 
Malone, S.J., Meert, J.G., Banerjee, D.M., Pandit, M.K., Tamrat, E., Kamenov, G.D., Pradhan, V.R., and Sohl, L.E., 2008, Paleomagnetism and detrital zircon geochronology of the upper Vindhyan sequence, Son Valley and Rajasthan, India: A ca. 1000 Ma closure age for the Purana Basins? Precambrian Research, v.164, pp.137-59.

Marmo, J. S., 1992. The Lower Proterozoic Hokkalampi Paleosol in North Karelia, Eastern Finland. M. Schidlowski et al. (Eds.) Early Organic Evolution: Implications for Mineral and Energy Resources (c) Springer-Verlag Berlin Heidelberg. pp. 41-66.

Meert, J.G., Pandit, M.K., Pradhan, V.R., Banks, J., Sirianni, R., Stroud, M., Newstead, B., and Gifford, J., 2010, Precambrian crustal evolution of Peninsular India: A 3.0-billion-year odyssey. Journal of Asian Earth Sciences, v. 39, pp. 483-515.

Meert, J.G., and Pandit, M.K., 2015, The Archaean and Proterozoic history of Peninsular India: tectonic framework for Precambrian sedimentary basins in India. In: Mazumder, R., and Eriksson, P. G. (Eds.), Precambrian Basins of India: Stratigraphic and Tectonic Context. Geological Society, London, Memoirs, 43, pp. 29-54, http://dx.doi.org/10.1144/M43.3

Mohanty, S.P., and Nanda, S., 2016, Geochemistry of a paleosol horizon at the base of the Sausar Group, central India: Implications on atmospheric conditions at the Archean-Paleoproterozoic boundary. Geoscience Frontiers, v. 7, pp.759-773.

Mukherjee,I., Large,R.R., Corkrey,R. and Danyushevsky, L.V., 2018,The Boring Billion,a slingshot for complex life on Earth. Scientific Reports, 8:4432, pp.1-7.

Mukhopadhyay, J., Ghosh, G., Zimserman, U., Guha, S., and Mukherjee, T., 2012, 3.51 Ga bimodal volcanics-BIF-ultramafic succession from Singhbhum Craton: implications for Palaeoarchaean geodynamic processes from the oldest greenstone succession of the Indian subcontinent. Geoscience Frontiers, v. 47, pp.284-311.

Mukhopadhyay, J., Crowley, Q.G., Ghosh, S., Ghosh, G., Chakrabarti, K., Misra, B., Heron, K., and Bose, S., 2014, Oxygenation of the Archean atmosphere: New paleosol constraints from eastern India. Geology, v.42 (10), pp. 923-926.

Mukhopadhyay, J., Misra, B., Chakrabarti, K., De, S., and Ghosh, G., 2016, Uraniferous paleoplacers of the Mesoarchean Mahagiri Quartzite, Singhbhum craton, India: Depositional controls, nature and source of $>3.0 \mathrm{Ga}$ detrital uraninites. Ore Geology Reviews,v.72,pp.1290-1306.

Murakami T., Kasama T. and Utsunomiya S., 2011, Early Proterozoic weathering processes under low $\mathrm{O} 2$ conditions reconstructed from a 2.45 Ga paleosol in Pronto, Canada. Am. Mineral. vol. 96, pp. 1613-1623.

Nelson, D.R., 1998, Granite-greenstone crust formation on the Archaean Earth-a consequence of two superimposed processes. Earth Planetary Science Letters, v.158, pp. 109-119.

Nelson, D.R, Trendall, A.F., and Altermann, W., 1999, Chronological correlations between the Pilbara and Kaapvaal cratons Precambrian Research, v.97, pp. 165-189.

Nelson, G.J., Pufahl, P.K., Hiatt, E.E., 2010, Plaeooceanographic constraints on Precambrian phosphorite accumulation, Baraga Group, Michigan, USA. Sedimentary Geology, v. 226, pp.9-21.

Ogg, J. G., Ogg, G., and Gradstein, F. M., 20016, The Concise Geologic Time Scale 2016.Amsterdam, Elsevier, 231 p.

Ohmoto H. and Rye R. 0., 1979, Isotopes of sulfur and carbon. In Geochemistry of Hydrothermal Ore Deposits, SecondEdition. (ed. H. L. Barnes), John Wiley and Sons, New York, Ch. IO pp. 509567.

Olson, S. L., Reinhard, C. T., Lyons, T. W., 2016, Cyanobacterial Diazotrophy and Earth's Delayed Oxygenation. Microbiological Chemistry and Geomicrobiology: Frontiers Microbiology, vol.
7:1526.

Pandit, M.K., Helga, D.W., and Chauhan, N.K., 2008, Paleosol at the Archean-Proterozoic contact in NW India revisited: Evidence for oxidizing conditions during paleo-weathering? Journal of Earth System Sciences, v.117, pp.201-209.

Papineau, D., 2010, Global biogeochemical changes at both ends of the Proterozoic: insight from phosphorites. Astrobiology, v.10, pp.165-181.

Pascoe, E. H., 1950, A manual of the geology of India and Burma. Govt. of India Press, Calcutta, 1:483.

Patranabis-Deb, S., Bickford, M.E., Hill, B., Chaudhuri, A.K., and Basu, A., 2007, SHRIMP ages of zircon in the uppermost tuff in Chhattisgarh Basin in central India require 500 Ma adjustment in Indian Proterozoic stratigraphy. Journal of Geology, v.115, pp. 407-415.

Paul, P.P., 2017, Autogenic and Allogenic controls on late Paleoproterozoic continental and marine sedimentation: Clues from Gwalior rift basin, Central India. Unpublished Ph.D. University of Delhi, Delhi, India, 254p.

Planavsky, N. J., McGoldrick, P., Scott, C. T., Li, C., Reinhard, C. T., Kelly, A. E., Chu, X., Bekker, A., Love, G. D., and Lyons, T. W., 2011, Widespread iron-rich conditions in the mid-Proterozoic ocean. Nature, v.47, pp. 448-451.

Planavsky, N.J., Reinhard, C.T., Wang, X.L., Thomson, D., McGoldrick, P., Rainbird, R.H., Johnson, T., Fischer, W.W., and Lyons, T.W., 2014, Low Mid Proterozoic atmospheric oxygen levels and the delayed rise of animals. Science, v.346, pp. 635638.

Pradhan, V.R., Meert, J.G., Pandit, M.K., Kamenova, G. and Mondal, M.E.A, 2012.Paleomagnetic and geochronological studies of the mafic dyke swarms of Bundelkhand craton, central India: Implications for the tectonic evolution and paleogeographic reconstructions. Precambrian Research v.198-199, pp. 51-76.

Poulton, S. W., Fralick, P. W., and Canfield, D. E., 2004, The transition to a sulphidic ocean similar to 1.84 billion years ago. Nature, v. 431, pp.173-177.

Pufahl, P.K., 2010, Bioelemental sediments. N.P. James, R.W. Dalrymple (Eds.), Facies Models (fourth ed.). Geological Association of Canada, pp.477-503.

Pufahl, P. K., and Haitt, E. E., 2012, Oxygenation of the Earth's atmosphere- ocean system: A review of physical and chemical sedimentologic responses. Marine and Petroleum Geology, vol. 32 (1), pp. 1-20.

Ramakrishnan, M., Vaidyanadhan, R., 2008, Geology of India. Bangalore; Geological Society of India, v.1, 2, 552p.

Rasmussen, B., and Buick, R., 1999, Redox state of the Archean atmosphere: evidence from detrital heavy minerals in ca. 32502750 Ma sandstones from the Pilbara Craton, Australia. Geology, v.27, pp.115-18.

Rasmussen, B., Bose, P. K., Sarkar, S., Banerjee, S., Fletcher, I. R., and M Cnaughton, N. J. 2002, 1.6 Ga U-Pb zircon age for the Chorhat Sandstone, Lower Vindhyan, India: possible implications for early evolution of animals. Geology, v.30, pp.103-6.

Ray, J.S., Martin, M.W., Veizer, J., and Bowring, S. A., 2002, U-Pb zircon dating and Sr isotope systematics of the Vindhyan Supergroup, India. Geology, v.30, pp.131-134.

Ray, J. S., Veizer, J., and Davis, W. J., 2003, C, O, Sr and Pb isotope systematics of carbonate sequences of the Vindhyan Supergroup, India: age, diagenesis, correlations and implications for global events. Precambrian Research, v.121, pp.103-140.

Ray, J. S., 2006, Age of the Vindhyan Supergroup: A review of recent findings. Journal of Earth System Science, v.115, pp.149-60.

Reddy, S. M. and Evans, D. A. D., 2009, Palaeoproterozoic supercontinents and global evolution: correlations from core to 
atmosphere. In: Reddy, S. M., Mazumder, R., Evans, D. A. D. \& Collins, A. (eds) Palaeoproterozoic Supercontinents and Global Evolution. Geological Society, London, Special Publications, vol. 323, pp. 1-26.

Reinhard, C.T., Planavsky, N.J., Robbins, L.J., Partin, C.A., Gill, B.C., Lalonde, S.V., Bekker, A., Konhauser, K.O., and Lyons, T.W., 2013, Proterozoic ocean redox and biogeochemical stasis. Proceedings National Academy Science U. S. A., v.110, pp.5357-5362.

Rybacki, K.S., Kumpa, L.R., Hanski, E.J., Melezhik, V.A., 2016, Weathering during the Great Oxidation Event: Fennoscandia, arctic Russia 2.06 Ga ago. Precambrian Research, vol. 275, pp. 513-525.

Rye, R., and Holland, H. D., 1998, Paleosols and the evolution of atmospheric oxygen: a critical review. American Journal of Science, v. 298, pp. 621-72.

Sarangi, S., Gopalan, K., and Kumar, S., 2004, Pb-Pb age of earliest megascopic, eukaryotic alga bearing Rhotas Formation, Vindhyan Supergroup, India: implications for Precambrian atmospheric oxygen evolution. Precambrian Research, v.132, pp.107-121.

Sarkar, A., Chakraborty, P.P. Mishra, B., Bera, M.K., Sanyal, P., and Paul, S., 2010, Mesoproterozoic sulphidic ocean, delayed oxygenation and evolution of early life: Sulphur isotope clues from Indian Proterozoic basins. Geolological Magazine, v.147 (2), pp. 206-218.

Scott, C., Lyons, T.W., Bekker, A., Shen, Y., Poulton, S.W., Chu, X., and Anbar, A. D., 2008, Tracing the stepwise oxygenation of the Proterozoic ocean. Nature v.452, pp. 456-459.

Shaw, G. H., 2014, Evidence and arguments for methane and ammonia in Earth's earliest atmosphere and an organic compound-rich early ocean. In: Shaw, G. H., (Ed.), Earth’s Early Atmosphere and Surface Environment. Geological Society of America Special Paper 504, pp.1-10.

Singh, A.K., Chakraborty, P.P., and Sarkar, S., 2018, Redox structure of Vindhyan hydrosphere: clues from total organic carbon, transition metal (Mo, Cr) concentrations and stable isotope ( $813 \mathrm{C})$ chemistry. Current Science, v. 115(7), pp.1334-1341.

Sinha, D.K., Raju, K.A., Bhaskar, D.V, and Asha, K., 2001, Sulphur isotopic characteristics of pyrite and galena from the Singhora Group, Chattisgarh Supergroup, India, genetic implications. Journal of the Geological Society of India, v.57, pp.171-7.

Slack, J. F., Grenne, T., Bekker, A., Rouxel, O. J., and Lindberg, P. A., 2007, Suboxic deep seawater in the late Paleoproterozoic: evidence from hematitic chert and iron formation related to seafloor-hydrothermal sulfide deposits, central Arizona, USA. Earth Planetary Science Letters, v.255, pp.243-256.

Smith, N.D., and Minter, W., 1980, Sedimentological controls of gold and uranium in Wit watersrand paleoplacers. Economic Geology, v.75, pp.1-14.

Srinivasan. R., and Ojakangas, R. W., 1986. Sedimentology of quartzpebble conglomerates and quartzites of the Archean Bababudan group, Dharwar craton, south India: evidence for early crustal stability’. Journal of Geology, vol. 94, pp. 199-214.

Sreenivas, B., and Srinivasan, R., 1994, Identification of paleosols in the Precambrian metapelitic assemblages of Peninsular India - a major element geochemical approach. Current Science, v. 67, pp.89-94.

Sreenivas, B., Roy, A. B., and Srinivasan, R., 2001, Geochemistry of sericite deposits at the base of the Paleoproterozoic Aravalli Supergroup, Rajasthan, India: Evidence for metamorphosed and metasomatised Precambrian Paleosol. Proceedings of the Indian Academy of Science (Earth Planetary Science), v. 110, pp. 3961.

Strauss, H., and Schieber, J., 1990, A sulphur isotope study of pyrite genesis: The Mid-Proterozoic Newland Formation, Belt Supergroup, Montana. Geochimica et Cosmochimica Acta, v.54, pp.197-204.

Strauss, H., 1997, The isotopic composition of sedimentary Sulphur through time. Palaeogeography, Palaeoclimatology Palaeoecology, v.132, pp.97-118.

Strauss, H., 1999, Geological evolution from isotope proxy signals sulphur. Chemical Geology, v.161, pp. 89-10.

Och, L. M., Shields-Zhou, G. A., 2012. The Neoproterozoic oxygenation event: Environmental perturbations and biogeochemical cycling. Earth-Science reviews, v.110, pp.2657.

Tang, D., Shia, X., Wang, X., and Jiang, G., 2016, Extremely low oxygen concentration in mid-Proterozoic shallow seawaters. Precambrian Research, v.276, pp.145-157.

Taylor, S.R., and McLennan, S.M., 1997, The origin and evolution of Earth's continental crust. Journal of Australian Geology and Geophysics, v.17, pp.52-62.

Wall, H. D., Pandit M.K., and Chauhan, N. K., 2012, Paleosol occurrences along the Archean-Proterozoic contact in the Aravalli craton, NW India. Precambrian Research, v. 216-219, pp. 120131.

Zachariah, J. K., Bhaskar Rao, Y. J., Srinivasan, R., and Gopalan, K. 1999, Pb, Sr and Nd isotope systematics of uranium mineralized stromatolitic dolomites from the Proterozoic Cuddapah Supergroup, south India: constraints on age and provenance. Chemical Geology, v.162, p.

Zahnle, K., Claire, M., and Catling, D., 2006, Methane, Sulfur, Oxygen, Ice The loss of mass independent fractionation in sulfur due to a Palaeoproterozoic collapse of atmospheric methane. Geobiology, vol. 4, pp. 271-283. 


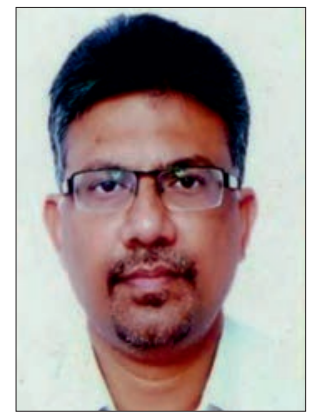

ParthaPratimChakraborty is Professor at University of Delhi, Delhi. He received his Masters in 1990 and Ph.D degree in 1996 from Jadavpur University, Kolkata, India. The research area of Prof. Chakraborty includes Proterozoic continental and shallow marine siliciclastic sedimentation in basins of varying tectonic settings, early Earth atmosphere and hydrosphere oxygenation etc. Since 2010 he has worked as a faculty at the University of Delhi. He has participated in several IGCP programs. Prof, Chakraborty is a recipient of National Mineral Award from Ministry of Mines, Govt. of India.

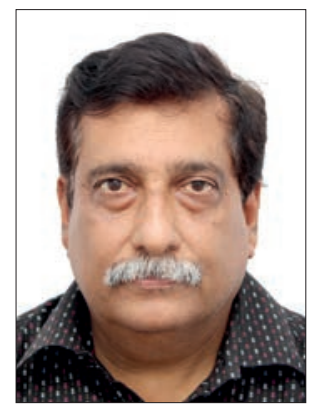

Prof. Joydip Mukhopadhyay has been teaching for the last three decades. He obtained his Bachelor's and Master's degrees in Geology from the University of Calcutta, Kolkata. He received his $\mathrm{PhD}$ from Jadavpur University and carried out postdoctoral research at the University of Johannesburg. The research area of Prof. Mukhopadhyay includes Proterozoic carbonate platforms, Archean greenstone and supracrustal sedimentary successions from India. He also takes interest in sediment-hosted iron and uranium mineralization in the Archean and Proterozoic successions. Prof. Mukhopadhyay has received National Mineral Award from the Minstry of Mines, India and INSA Teachers Award from the Indian National Science Academy.

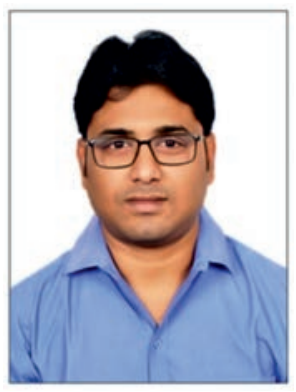

Pritam P Paul is Assistant Professor at Manav Rachna International Institute of Research and Studies, Faridabad, India. He received his M.Sc. in Geology in 2008 from Amravati University, India and Ph.D. in Geology in 2017 from University of Delhi, India. From 2017 to 2019 he has worked as $\mathrm{N}-\mathrm{PDF}$ at Indian Institute of Technology Bombay, India. 